\title{
Hasi cysták és cystosus képletek differenciáldiagnózisa gyermekkorban
}

\author{
Józsa Gergő dr. - Mohay Gabriella dr. - Pintér András dr. \\ Vástyán Attila dr.
}

Pécsi Tudományegyetem, Klinikai Központ, Gyermekklinika, Gyermeksebészeti Osztály, Pécs

\begin{abstract}
A Pécsi Gyermekklinika Sebészeti Osztályán 2010 és 2013 között 19 gyermekben diagnosztizáltak különböző eredetű hasi cystát, amelyek közül a szerzők egy parovarialis cystát, egy bélduplikatúrát és egy omentumcystát részletesen is tárgyalnak, kiemelve a klinikai tüneteket, a kórismézési módszereket és a mütéti kezelést. Megállapítják, hogy a hasi cystosus folyamatok gyakran csak enyhe panaszokat okoznak és más okból végzett ultrahangvizsgálat során véletlenül kerülnek felismerésre. Néhány esetben a hasi cysta komoly panaszokat okoz, esetleg akut has képében jelentkezik, ezekben az esetekben azonnali mútétre lehet szükség. A laparoszkópia mind a diagnosztikában, mind a sebészeti ellátásban értékes módszer. Hasi komputertomográfiás vagy mágneses rezonanciavizsgálatra a betegek többségének nincs szüksége. Orv. Hetil., 2015, 156(37), 1509-1513.
\end{abstract}

Kulcsszavak: hasi cysták, ovariumtorzió, bélduplikatúra, diagnosztikus laparoszkópia

\section{Differential diagnosis of abdominal cysts in children}

\section{Case report}

19 children were diagnosed with abdominal cysts of different origin in the Surgical Unit of the Department of Pediatrics, Medical University of Pécs, Hungary between 2010 and 2013. The authors discuss the details of representative cases of a parovarial cyst, an intestinal duplication, and an omental cyst with emphasis on the clinical symptoms, diagnostic tools, and surgical interventions. The authors conclude that abdominal cysts often cause mild symptoms only, and they are discovered accidentally by ultrasound imaging performed for other reasons. In some cases, the cyst can cause severe complaints or even acute abdomen requiring emergency surgery. Laporoscopy may be a valuable method both in diagnosis and surgical therapy. Abdominal CT or MRI are not required in the majority of the patients.

Keywords: abdominal cysts, ovarian torsion, intestinal duplication, diagnostic laparoscopy

Józsa, G., Mohay, G., Pintér, A., Vástyán, A. [Differential diagnosis of abdominal cysts in children. Case reports]. Orv. Hetil., 2015, 156(37), 1509-1513.

(Beérkezett: 2015. június 17.; elfogadva: 2015. július 16.)

A hasi cystosus terimék - petefészekcysta, parovarialis cysta, gastrointestinalis duplikáció, lymphangioma, mesenterium-, omentum-, choledochuscysta, elülső meningomyelokele, omphaloentericus cysta, urachuscysta, hydrometrocolpos [1, 2] - differenciáldiagnosztikai problémát jelenthetnek mind újszülött-, mind gyermekkorban. Újszülött lányokban a hasi cysták leggyakrabban petefészek-eredetüek [3]. Legnehezebb a petefészekcys- ta és a bélduplikatúra elkülönítése [4]. Gastrointestinalis kettőzetek leggyakrabban a vékonybelet érintik, azon belül is az ileumot, míg a gyomor és a vastagbél duplikációja ritka $[5,6]$. A cysták kialakulásának több lehetséges magyarázata van, pontos oka azonban nem ismert.

2010 és 2013 között 19 csecsemóben és gyermekben diagnosztizáltunk különböző eredetű hasi cystosus elváltozást a Pécsi Gyermekklinika Sebészeti Osztályán. A be- 
A 19 beteg tünettanát, kivizsgálását és kórismézését, valamint az alkalmazott terápiát összefoglaló táblázat. A részletesen ismertetett eseteket (9., 13., 15.) a kiemelt sorok mutatják

\begin{tabular}{|c|c|c|c|c|c|c|c|c|c|c|c|c|c|c|c|}
\hline & \multirow[t]{2}{*}{ Nem } & \multirow{2}{*}{$\begin{array}{l}\text { Életkor } \\
\text { (hónap) }\end{array}$} & \multicolumn{3}{|c|}{ Tünet } & \multicolumn{5}{|c|}{ Kórisme } & \multicolumn{3}{|c|}{ Terápia } \\
\hline & & & & & Hasfájás & Hányás & $\begin{array}{l}\text { Tapint- } \\
\text { hatóság }\end{array}$ & $\mathrm{UH}$ & $\begin{array}{l}\text { Rönt- } \\
\text { gen }\end{array}$ & CT & MR & Lap. & $\begin{array}{l}\text { Nyílt } \\
\text { mútét }\end{array}$ & Lap. & $\begin{array}{l}\text { Kon- } \\
\text { verzió }\end{array}$ \\
\hline 1. & & funkcionális & 1 & 15 & + & + & & + & + & - & - & + & - & - & + \\
\hline 2. & \multirow{11}{*}{$\begin{array}{l}\text { Ovarium- } \\
\text { cysta }\end{array}$} & \multirow{6}{*}{ serosus } & 1 & 18 & + & - & - & + & - & - & - & + & - & - & + \\
\hline 3. & & & 1 & 192 & + & - & - & + & - & - & - & + & - & + & - \\
\hline 4. & & & 1 & 204 & + & + & - & + & - & - & - & - & + & - & - \\
\hline 5. & & & 1 & 192 & + & - & + & + & - & - & - & + & - & + & - \\
\hline 6. & & & 1 & 180 & + & + & - & + & - & - & - & + & - & - & + \\
\hline 7. & & & 1 & 192 & + & - & - & + & - & - & - & + & - & + & - \\
\hline 8. & & \multirow{2}{*}{ parovarialis } & 1 & 204 & + & - & + & + & - & - & - & + & - & + & - \\
\hline 9. & & & 1 & 180 & + & - & + & + & - & - & - & - & + & - & - \\
\hline 10. & & \multirow{2}{*}{ dermoid } & 1 & 106 & + & + & - & + & + & - & - & + & - & - & + \\
\hline 11. & & & 1 & 132 & + & - & - & + & + & - & - & + & - & + & - \\
\hline 12. & & $\begin{array}{l}\text { hormontermel”̋ } \\
\text { daganat }\end{array}$ & 1 & 30 & + & + & - & + & - & - & - & - & + & - & - \\
\hline 13. & \multirow{2}{*}{\multicolumn{2}{|c|}{ Jejunumduplikatúra }} & 1 & 52 & + & - & - & + & - & - & - & + & - & - & + \\
\hline 14. & & & $\mathrm{f}$ & 132 & + & - & - & + & - & - & - & + & - & - & + \\
\hline 15. & \multirow{2}{*}{\multicolumn{2}{|c|}{ Mesenterium-omentum cysta }} & $\mathrm{f}$ & 64 & + & - & + & + & - & - & - & - & + & - & - \\
\hline 16. & & & $\mathrm{f}$ & 75 & + & - & + & + & - & - & + & - & + & - & - \\
\hline 17. & \multicolumn{2}{|c|}{ DOEP-cysta } & $\mathrm{f}$ & 180 & + & - & - & + & - & - & - & + & - & + & - \\
\hline 18. & \multicolumn{2}{|l|}{ Májcysta } & 1 & 120 & + & - & - & + & - & - & + & + & - & + & - \\
\hline 19. & \multicolumn{2}{|c|}{ Urachuscysta } & $\mathrm{f}$ & 117 & + & - & - & + & - & - & - & - & + & - & - \\
\hline
\end{tabular}

f = fiú; l = leány; Lap. = laparoszkópia

tegek tünettanát, kivizsgálását és kórismézését, valamint az alkalmazott terápiát az 1 . táblázat részletezi. A betegek közül 12 esetben petefészek-, míg 6 gyermeknél béltraktus- és 1 esetben húgyúti eredetû cystosus folyamat miatt végeztünk mütétet. Három beteg (parovarialis, omentumcysta és a bélduplikatúra) kórtörténetét részletesen ismertetjük.

\section{Esetismertetések}

\section{Első beteg}

A 15 éves leányt (1. táblázat, 9. beteg) magas vérnyomás miatt gondozták. Az egyébként panaszmentes leánygyermeknél az elődomborodó alhas miatt hasi ultrahangvizsgálat történt, amely a kismedence mindkét oldalán a hasüregbe terjedő, $25 \mathrm{~cm}$ átmérőjű, vékony falú cystosus képleteket mutatott (1. ábra). A laboratóriumi vizsgálat kóros eltérést nem igazolt. A vizsgálatok alap-

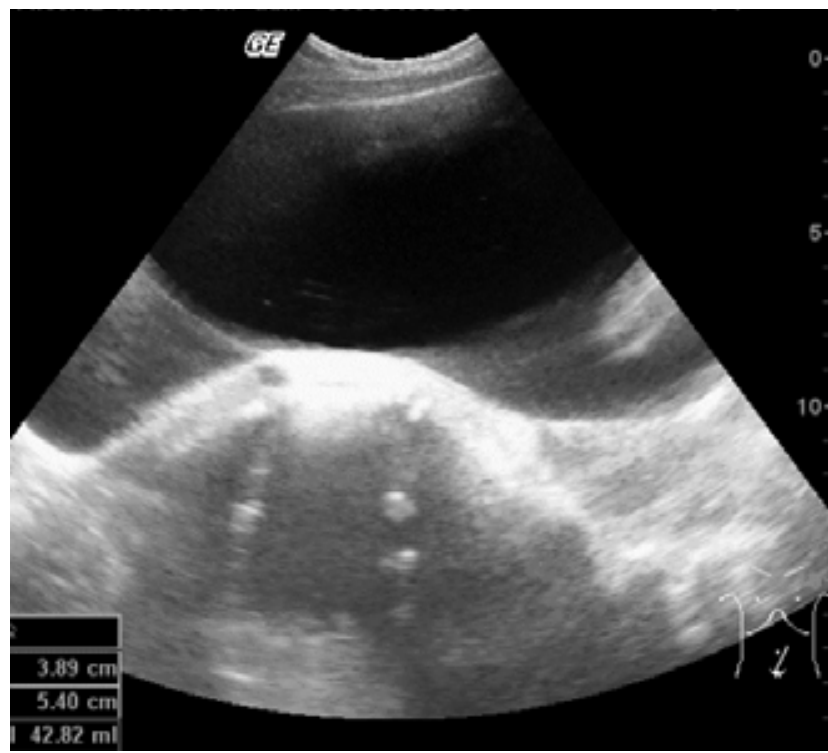

1. ábra | A hasi ultrahangvizsgálat a kismedencében nagy kiterjedésű, vékony falú cystosus képletet mutat 


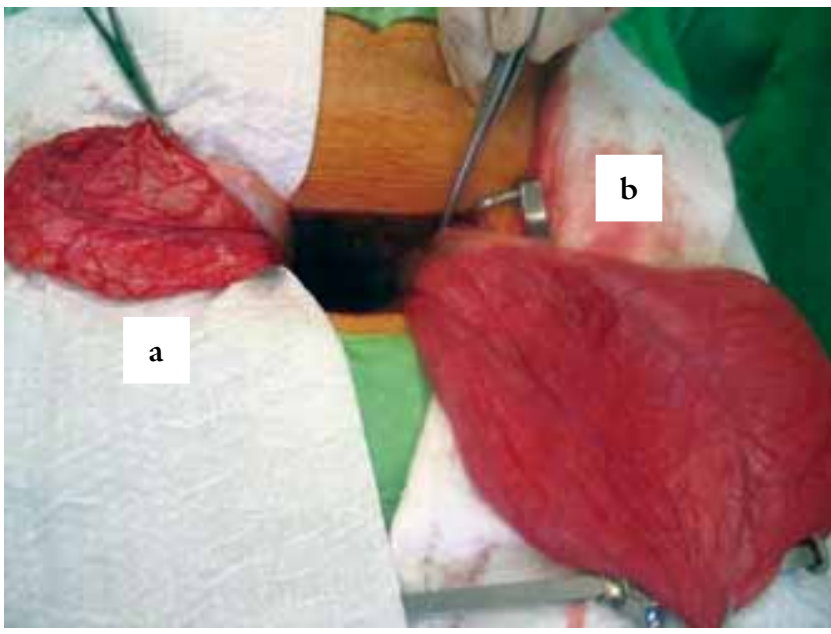

2. ábra

A jobb oldali mesosalpinxban (a) $800 \mathrm{ml}$, a bal oldali mesosalpinxban (b) $2000 \mathrm{ml}$ folyadékot tartalmazó parovarialis cysta látható

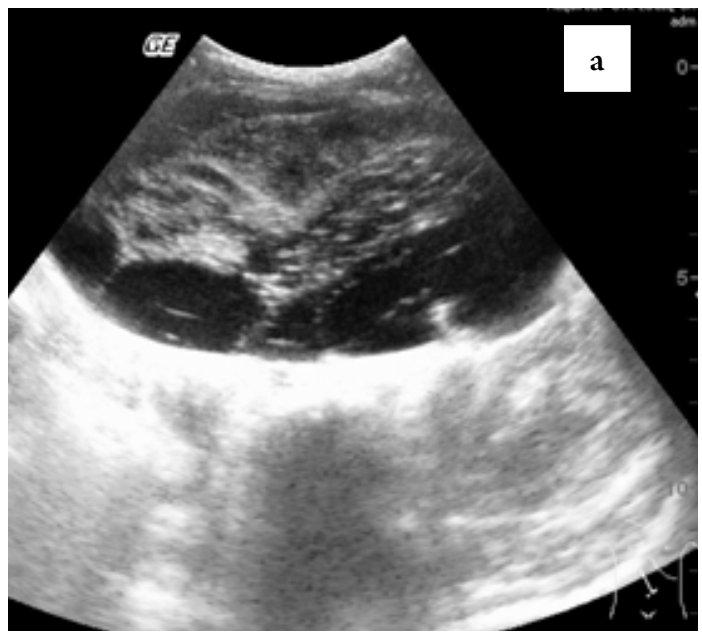

4. ábra

a) Az ultrahangfelvételen gú omentumcysta látható

ján parovarialis cysta diagnózisát állítottuk fel. Tekintettel a cysták nagyságára, mütétet végeztünk. Pfannenstielmetszésből végzett exploratív laparotomia során a bal oldali mesosalpinxban $2000 \mathrm{ml}$, a jobb oldali tuba uterina hashártyakettőzetében $800 \mathrm{ml}$ folyadékot tartalmazó parovarialis cystát távolítottunk el mindkét ovarium megtartásával (2. ábra).

\section{Második beteg}

A 4 éves leányt (1. táblázat, 13. beteg) visszatérő enyhe hasi panaszok miatt vizsgáltuk. Az ultrahangvizsgálat $8 \times 5 \times 4,5 \mathrm{~cm}$-es, híg folyadéktartalmú, szedimentumokat tartalmazó, $90 \mathrm{ml}$ volumenú cystosus képletet írt le a jobb petefészek vetületének megfelelően. Az elváltozást nagy valószínűséggel petefészek-eredetûnek véleményezték, de a megismételt ultrahangvizsgálat a bélduplikatúra lehetőségét is felvetette. A diagnózis bizonytalan-

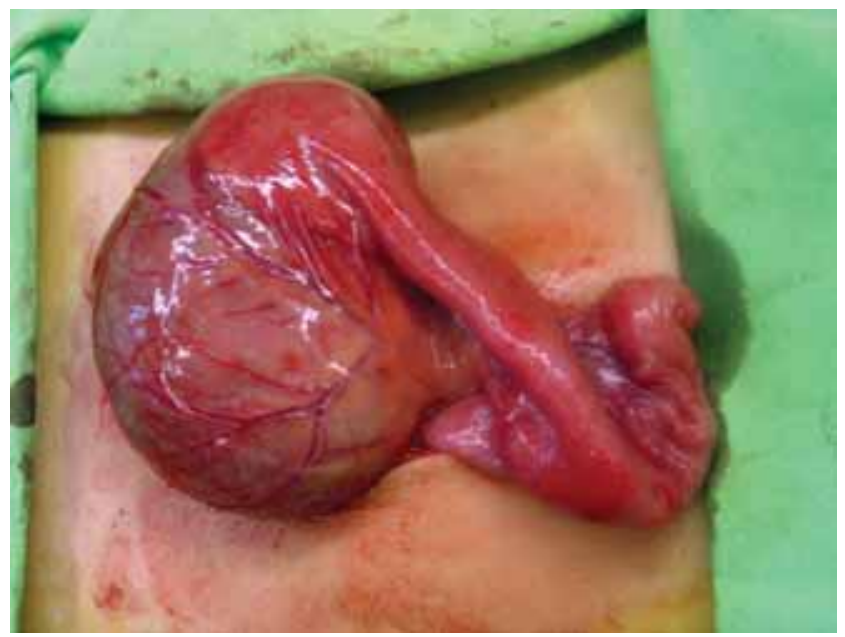

3. ábra

Cystosus, $8 \times 5 \times 4,5 \mathrm{~cm}$-es, híg folyadéktartalmú, jejunumot érintő bélduplikatúra intraoperatív képe

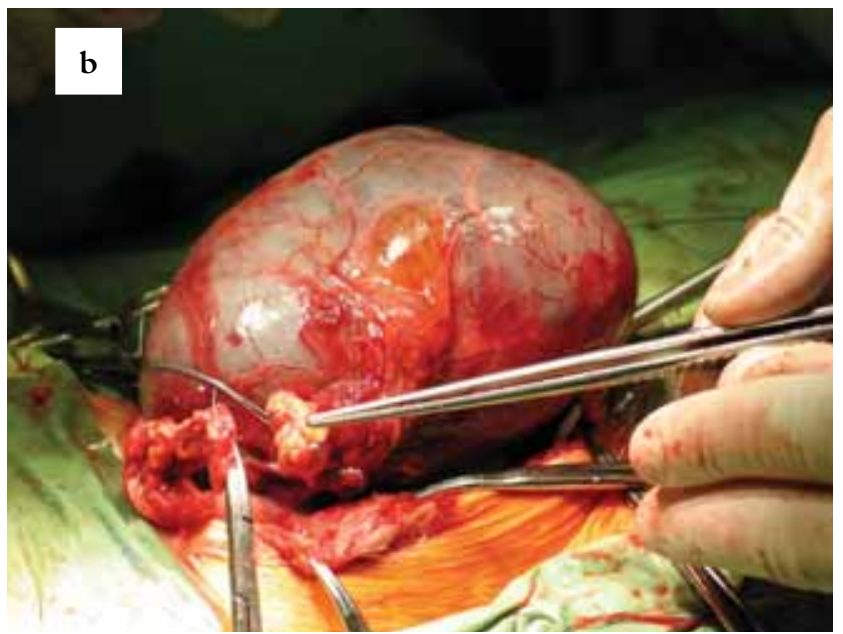

sága miatt diagnosztikus laparoszkópia történt, amely cystosus jejunalis bélduplikatúrát igazolt (3. ábra). A diagnózis felállítása után a mútétet konvertáltuk, a jejunumduplikatúrát az ép bélszakasszal együtt reszekáltuk. A $4 \mathrm{~cm}$ hosszú cystosus vékonybélkettőzet a natív béllel nem közlekedett. A szövettani vizsgálat vékonybél- (jejunum-) duplikatúrát igazolt.

\section{Harmadik beteg}

Az 5 éves fiú (1. táblázat, 15. beteg) egy hete tartó hasi panaszok miatt került klinikánk sebészeti ambulanciájára. Korábban a gyermeknek hasi panaszai nem voltak. Fizikális vizsgálat során a köldöktől cranialisan elődomborodó, a hasüreg egy részét kitöltő, mobilis $10-15 \mathrm{~cm}$ es rezisztenciát tapintottunk. A hasi ultrahangvizsgálat $14 \times 7 \mathrm{~cm}$-es, $300 \mathrm{ml}$ volumenü hasi cystát írt le (4. a) ábra). A laboratóriumi vizsgálat emelkedett gyulladásos 
értékeken kívül egyéb kórosat nem mutatott. Exploratív laparotomia során $15 \times 10 \mathrm{~cm}$ nagyságú, a hasfalhoz és a bélkacsokhoz kitapadt, a nagycsepleszben elhelyezkedő omentumcystát távolítottunk el (4. b) ábra). A hisztológiai vizsgálat cysticusan degenerálódott haematomát írt le.

\section{Megbeszélés}

A hasi cysták gyermekkori előfordulása nem gyakori, esetenként csak enyhe panaszokat okoznak és csak más okból végzett ultrahangvizsgálat során, véletlenül kerülnek felismerésre. Néhány esetben a hasi cysta akut has képében jelentkezik, ezekben az esetekben azonnali mútétre lehet szükség.

A hasi cystosus folyamatok lánygyermekekben gyakran petefészek-eredetúek, míg fiúkban leggyakrabban a gastrointestinalis traktus érintett. Az abdominalis cysták diagnózisának előzetes felállítása az esetek döntő hányadában a fizikális vizsgálat és az ultrahang alapján történik.

A közleményben ismertetett betegekben a fizikális vizsgálat valószínúsítette, majd az ultrahang igazolta a has különböző régióiban elhelyezkedő, különböző eredetü cystosus folyamatokat.

Az ultrahang egyszerűen kivitelezhető, gyors, nem invazív, megfelelő gyakorlattal rendelkező radiológus kezében igen hatékony és megbízható diagnosztikai vizsgálómódszer. Differenciáldiagnosztikai nehézség esetén laparoszkópia, esetleg MR-vizsgálat segíthet a helyes diagnózis felállításában. A laparoszkópia mind a diagnosztikában, mind a sebészeti ellátásban értékes módszer. A közleményben bemutatott gyermekek közül 13 esetben végeztünk laparoszkópiát, amely során 7 esetben laparoszkópiával egy időben terápiás beavatkozásra is sor került, míg 6 esetben a laparoszkópia csak diagnosztikus volt. A diagnosztikus laparoszkópia nemcsak a kórisme felállításában nyújthat segítséget, hanem a mütéti megoldás módjának megválasztásában is. A jelentős sugárterheléssel járó CT-vizsgálatra, véleményünk szerint, csak ritkán van szükség.

Ovarialis eredetű térfoglalások esetén két fö csoportot különíthetünk el, a nem neoplasztikus és a neoplasztikus elváltozásokat. A nem neoplasztikus ovariumelváltozások: a funkcionális, a serosus petefészekcysták, a parovarialis cysták és a benignus petefészektumorok, ezek kezelése a cysta méretétől függ [7]. A 4-5 cm-nél kisebb méretú cysták esetén megfigyelés, 3 havonkénti kontrollultrahangvizsgálat javasolt. Nagyobb méretű cysták obszervációja esetén hatványozottan számolnunk kell a megcsavarodás lehetőségével, így ezekben a betegekben mútéti eltávolítás javasolt nyílt feltárással vagy laparoszkópos technikával [8]. A közleményünkben ismertetett gyermekekben benignus elváltozásokat diagnosztizáltunk. A malignus ovariumtumorok előfordulása gyermekkorban ritka, különösen ötéves kor alatt [9]. Az öszszes malignus gyermekkori tumorok mindössze $0,9 \%$-át teszik ki [10].
Az ovariumtorzió előfordulása gyermek- és serdülőkorban viszonylag ritka, leggyakrabban valamilyen patológiai eltérés (ovarialis, parovarialis, dermoid cysta) áll a hátterében [11]. A sürgős mütétet igénylő esetekben (ovariumtorzió, illetve a parovarialis, ovarialis cysta bevérzése, megtekeredése) fontos a gyors és pontos diagnózis felállítása. A kórisme felállításának legfontosabb eleme a color Doppler-ultrahangvizsgálat, amely jól mutatja a keringés károsodását az érintett petefészekben. Amennyiben az ultrahangvizsgálat a petefészek keringésének károsodását, perfúziójának csökkenését mutatja, úgy azonnali mütét elvégzése szükséges. A mütéti megoldások közül a laparoszkópos eljárás egyre elterjedtebbé vált a gyermeksebészek körében is. Amennyiben a laparoszkópia nem kivitelezhető vagy nem sikeres, úgy nyílt mútéti feltárás szükséges. Ha a petefészek keringése a detorquatiót követően megtartott, akkor a petefészek eltávolítása nem célszerü, hanem csak a cysta reszekciója indokolt. Egyes szerzők előrehaladott ischaemiás károsodás esetén sem ajánlják a petefészek eltávolítását, mert a makroszkóposan látható érintettség nem minden esetben korrelál az ischaemia fokával [12]. Gyakorlatunkban csak az egyértelmú irreverzíbilis ischaemiás károsodás jeleit mutató petefészket távolítjuk el az esetleges szövődmények (tályogképződés, diffúz peritonitis) megelőzése érdekében.

A gastrointestinalis duplikációk előfordulása ritka, leggyakrabban érintett bélszakasz az ileum [5]. A bélduplikatúra lehet cysticus, elsősorban a vékonybélben, tubularis (döntően vastagbélben) vagy ritkán kevert típusú. Leggyakoribb klinikai tünetek a hasi fájdalom, a tapintható hasi terime, valamint a gastrointestinalis vérzés és/vagy intestinalis obstrukció [13]. A diagnosztikus módszerek közül a fizikális és az ultrahangvizsgálat végzendő. A felismert cysta eredetének tisztázásában a laparoszkópia nyújt segítséget, amely egyidejűleg terápiás megoldást is jelenthet. Mútéti megoldás az érintett normális bélszakasz reszekciója, a normális vékonybél mesenterialis oldalán elhelyezkedő kettőzettel együtt. Betegeinkben a kettőzet nem típusos lokalizációban, hanem a jejunumon helyezkedett el. A diagnózist laparoszkópia segítségével állítottuk fel, az érintett bélszakaszt minilaparotomia során távolítottuk el.

$\mathrm{Az}$ omentumcysta előfordulása rendkívül ritka, egyazon embriológiai struktúrából, hasonló patogenezissel alakul ki, mint az ectopiás nyirokszövet [14]. A diagnózis általában véletlenszerú, bizonytalan hasi panaszok hívhatják fel a figyelmet az elváltozásra. Súlyos szövődményekkel járhat, heveny hasi tünetek képében jelentkezhet. A cysta, méreténél és súlyánál fogva, megcsavarodhat, volvulust okozhat, keringési zavarok következtében kiterjedt vérzés, nekrózis léphet fel [15]. Az irodalmi adatok is szerények e kórkép tekintetében, mert a kisszámú eset miatt kevés klinikai információ áll rendelkezésünkre. A közleményünkben ismertetett fiúgyermeknél 1 hete fennálló bizonytalan hasi panaszok hívták fel a figyelmet a hasi cystára, amelyet a hasi ultra- 
hangvizsgálat valószínűsített. Exploratív laparotomia során távolítottuk el az omentumban lévő $11 \mathrm{~cm}$ átmérőjü cystát. A cysta falának a szövettani vizsgálata csak részben támasztotta alá az omentumcysta kórisméjét.

\section{Következtetések}

Betegeink kórtörténetének elemzése alapján típusos hasi cysták esetében sugárterheléssel járó CT-vizsgálat általában nem szükséges, fooleg akkor, ha a laparoszkópos vagy nyílt mútét egyébként is indokolt.

Anyagi támogatás: A közlemény megírása anyagi támogatásban nem részesült.

Szerzői munkamegosztás: J. G.: A közlemény megírása. M. G.: A radiológiai vizsgálatok értékelése. P. A., V. A.: A közlemény céljának és üzenetének megfogalmazása, a dolgozat ellenőrzése, javítása. A cikk végleges változatát a valamennyi szerző elolvasta és jóváhagyta.

Érdekeltségek: A szerzőknek nincsenek érdekeltségeik.

\section{Irodalom}

[1] Helmrath, M. A., Shin, C. E., Warner, B. W.: Ovarian cysts in the pediatric population. Semin. Pediatr. Surg., 1998, 7(1), 19-28.

[2] Vogtländer, M. F., Rijntjes-Jacobs, E. G., van den Hoonaard, T. L., et al.: Neonatal ovarian cysts. Acta Paediatr., 2003, 92(4), 498501 .

[3] Brandt, M. L., Helmrath, M. A.: Ovarian cysts in infants and children. Semin. Pediatr. Surg., 2005, 14(2), 78-85.

[4] Godfrey, H., Abernethy, L., Boothroyd, A.: Torsion of an ovarian cyst mimicking enteric duplication cyst on transabdominal ultrasound: two cases. Pediatr. Radiol., 1998, 28(3), 171-173.
[5] Stringer, M. D., Spitz, L., Abel, R., et al.: Management of alimentary tract duplication in children. Br. J. Surg., 1995, 82(1), 7478.

[6] Patel, M. P., Meisheri, I. V., Waingankar, V. S., et al.: Duplication cyst of the pylorus - a rare cause of gastric outlet obstruction in the newborn. J. Postgrad. Med., 1997, 43(2), 43-45.

[7] Liu, H., Wang, X., Lu, D., et al.: Ovarian masses in children and adolescents in China: analysis of 203 cases. J. Ovarian Res., $2013,6,47$.

[8] Kurtz, R. J., Heimann, T. M., Holt, J., et al.: Mesenteric and retroperitoneal cysts. Ann. Surg., 1986, 203(1), 109-112.

[9] Deligeoroglou, E., Eleftheriades, M., Shiadoes, V., et al.: Ovarian masses during adolescence: clinical, ultrasonographic and pathologic findings, serum tumor markers, and endocrinological profile. Gynecol. Endocrinol., 2004, 19(1), 1-8.

[10] Brookfiled, K. F., Cheung, M. C., Koniaris, L. G., et al.: Population based analysis of 1037 malignant ovarian tumors in the pediatric population. J. Surg. Res., 2009, 156(1), 45-49.

[11] Kokoska, E. R., Keller, M. S., Weber, T. R.: Acute ovarian torsion in children. Am. J. Surg., 2000, 180(6), 462-465.

[12] Shalev, J., Goldenberg, M., Oelsner, G., et al.: Treatment of twisted ischemic adnexa by simple detorsion. N. Engl. J. Med., 1989, $321(8), 546$.

[13] Lipsett, J., Sparnon, A. L., Byard, R. W.: Embryogenesis of enterocystomas-enteric duplication cysts of the tongue. Oral Surg. Oral Med. Oral Pathol., 1993, 75(5), 626-630.

[14] Nam, S. H., Kim, D. Ү., Kim, S. C., et al.: The surgical experience for retroperitoneal, mesenteric and omental cyst in children. J. Korean Surg. Soc., 2012, 83(2), 102-106.

[15] Pilaszanovich, I., Kustos, Gy., Pintér, A., et al.: Mesenteric and omental lymphocysts manifested during childhood. [A gyermekkorban manifesztálódott mesenterialis és omentalis lympcystákról.] Orv. Hetil., 1974, 115(31), 1811-1814. [Hungarian]

(Józsa Gergő dr., Pécs, József A. u. 7., 7623 e-mail: jozsag84@freemail.hu)

\section{Az Orvosi Hetilap 2015, 156, 1272. oldalán (31. szám) megjelent OH-Kvízre egy helyes megfejtés érkezett.}

A beküldő: Dr. Bíró László (Budapest).

A nyertesnek szívböl gratulálunk.

$$
\begin{aligned}
& \text { A nyereményét - egy, az Akadémiai Kiadó webáruházában } \\
& \text { kedvezményes vásárlásra jogosító kupont - e-mailen küldjük el. }
\end{aligned}
$$

